\title{
Milk and dairy products: possible effects on dental health
}

\author{
Ingegerd Johansson
}

Department of Cariology, Umeå University, Umeå, Sweden

\begin{abstract}
Milk and dairy products have a low cariogenic potential, but they are also claimed to be cariostatic. Thus, bovine milk and cheese provide protection against caries in rats and in situ, even in caries-susceptible conditions. The mechanisms involve several milk components and effects. Caseins and peptides thereof, i.e. casein glycomacropeptide (CGMP) and casein phosphopeptide (CPP), reduce the adhesion of cariogenic mutans streptococci in situ and seem to reduce colonization in the rat. They block adhesion in solution (clearance), as well as when bound to tooth surfaces. CGMP binds to the tooth as micelle-like structures, which do not bind bacteria. CPP binds as minor complexes with calcium and phosphate, buffering calcium and phosphate when hydroxyapatite solubility increases by decreasing $\mathrm{pH}$, and possibly explaining the acid-buffering effect from milk and cheese. Further, peptides in the whey fraction, i.e. proteose-peptones, provide protection against tooth tissue demineralization, and other milk peptides, such as kappacin (a $\kappa$-casein-derived peptide), lactoferrin, lactoperoxidase and lysozyme, possess innate immunity-like functions. Using milk components as a caries-prophylactic measure has not been studied in humans, but epidemiological studies confirm associations between milk/cheese intake and protection against caries. However, the impact of possible confounders cannot yet be fully evaluated.
\end{abstract}

Keywords: Cheese, dental caries, milk, peptides, S. mutans.

Received: 14 March 2002; Accepted: 9 April 2002

\section{Association of milk and cheese with low caries development}

Milk and dairy products comprise a substantial part of the food consumed in Sweden (1), but even though overall mean intake is high substantial individual variations are seen in the population. Milk intake has been negatively correlated with the development of dental caries in children (2) and adolescents (3). Thus, those with low caries development drank more milk than those with high caries development. The strongest association was among children with high sucrose intake (2). Similarly, root surface caries development was halved in elderly people who ate cheese five or more times per week compared with those with one or fewer intakes per week (4). The aim of the present review is to describe the state of the art of possible anticariogenic properties of milk and cheese.

\section{Effect of milk and cheese on demineralization and remineralization of tooth tissues}

\section{A nimal studies and in situ human studies}

In 1959 Shaw et al. reported that milk, ice cream and cheese reduced caries development in rats (5). Several investigators have since confirmed that milk, cheese, caseins and whey proteins reduce caries development from sucrose even in highly susceptible rats, such as after desalivation (6-9). These results are supported by a large number of in situ studies, e.g. using enamel discs carried in the human mouth (10). Using this model cheese even restores demineralized enamel in head- and neck-irradiated xerostomic patients (11).

\section{Prevention of fall in $\mathrm{pH}$ in tooth biofilms}

Milk contains $4-5 \%$ of the disaccharide lactose, which can be fermented by oral biofilm bacteria; however, unless the bacteria are adapted to lactose, fermentation is significantly less than from sucrose (Fig. 1a) (12, 13). Normally, sucrose lowers $\mathrm{pH}$ below 5.0, whereas lactose lowers it to around 6.0. With some individual variations, $\mathrm{pH}$ lower than 5.5 is hazardous to tooth enamel and lower than 6.2 to root tissues. Thus, under normal conditions the carbohydrate content of milk confers a low cariogenic potential to milk and dairy products. However, drinking milk (12) or chewing on cheese (10, 
14) counteracts the acidification induced by sucrose in the dental biofilm (Fig. 1b). The clinical impact of this is unknown but, theoretically, diminished periods of acidification and demineralization may contribute to tooth preservation.

\section{Prevention of tooth demineralization}

Removal of casein, fat or lactose from the milk does not affect its protective capacity on demineralization (15). Free calcium and phosphate have some effect, but after removal of all these components milk still contains powerful protective factors identified as water-soluble proteose-peptones, amounting to $1 \mathrm{~g}^{-1}$ milk (15).

\section{Prevention by milk of the adhesion of cariogenic Streptococcus mutans bacteria to tooth surfaces}

Biofilm formation on teeth involves three distinct
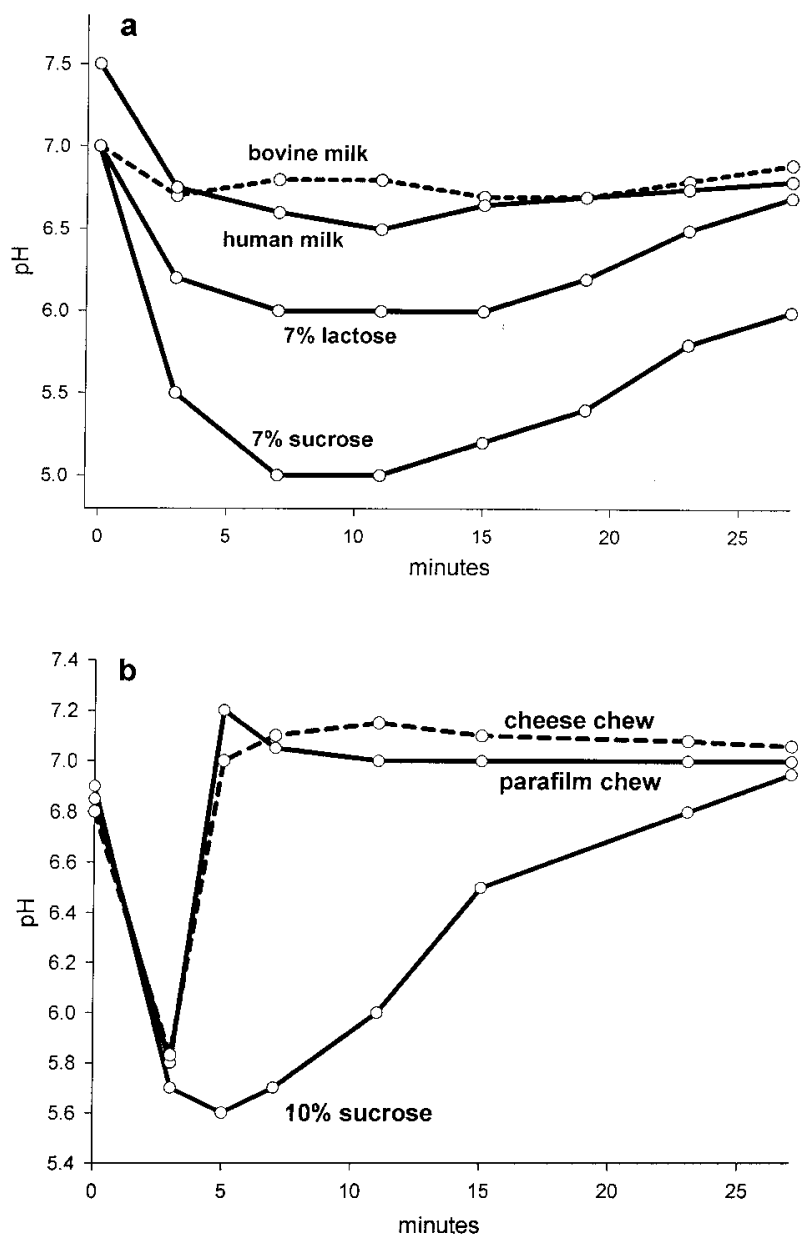

Fig. 1. (a) pH lowering by bovine and human milk compared with water solutions of lactose or sucrose. (b) $\mathrm{pH}$ neutralizing effect by cheese intake following a sucrose rinse. Reconstructed from Refs (12) and (14), respectively.

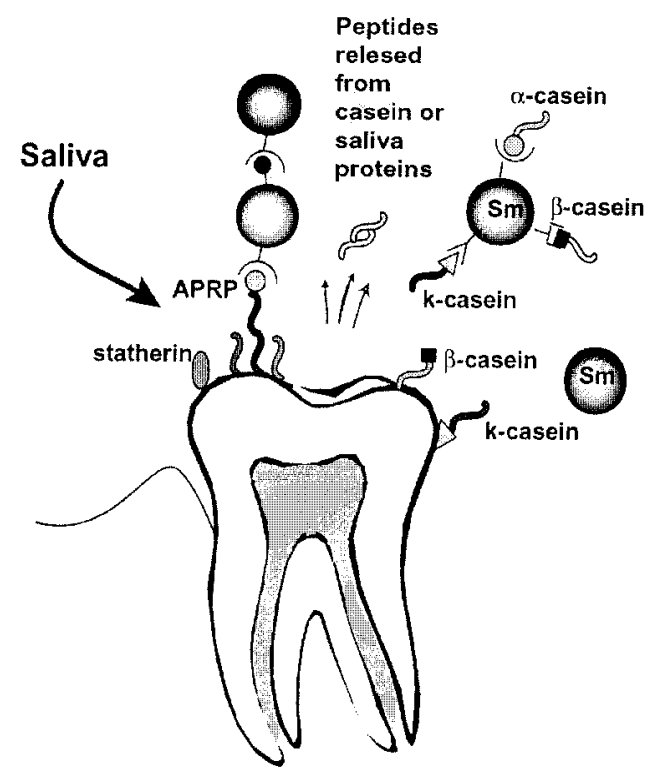

Fig. 2. Biofilm formation on teeth involving milk caseins and saliva proteins, e.g. acidic proline rich proteins (APRP) and statherin. $\alpha_{-}, \beta$ - and $\kappa$-caseins inhibit the adhesion of Streptococcus mutans $(\mathrm{Sm})$, and peptides released from caseins may inhibit the growth of oral opportunistic microorganisms.

phases (Fig. 2): (i) pellicle formation, i.e. adhesion of salivary proteins/polypeptides (or from other sources, such as serum or milk); (ii) attachment of bacteria to pellicle proteins through the matching of bacteria adhesins to host receptors; and (iii) multiplication of the attached bacteria (environmentally driven, such as $\mathrm{pH}$ and access of nutrients). Colonization is established.

No single species of bacteria fully explains caries development, but mutans streptococci are frequently found in higher numbers on caries-active than non-active sites, and Streptococcus mutans adhesion is associated with caries susceptibility (16). Milk abolishes the adhesion of $S$. mutans to saliva-coated hydroxyapatite (17-20), possibly

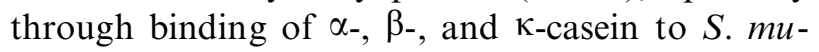
tans in solution (Table 1), and blocking by large micelle-like $\kappa$-casein structures bound onto hydroxyapatite (21). Peptides derived from $\kappa$ - and $\beta$-casein fractions, i.e. casein glycomacropeptide (CGMP) and caseinophosphopeptide (CPP), respectively, incorporated into the salivary pellicle by displacing albumin, confer adhesion inhibition (22). In addition, milk and $\kappa$-casein significantly reduce the adsorption to teeth of glucosyltransferase (GTF, a polysaccharide-producing enzyme from, for instance, S. mutans (23). 
Table I. Effect of various casein fractions on events associated with the adhesion of Streptococcus mutans

\begin{tabular}{|c|c|c|c|c|c|}
\hline & \multirow{2}{*}{$\begin{array}{l}\text { Binding to S. mutans } \\
\text { Casein in solution }\end{array}$} & \multicolumn{2}{|c|}{ Inhibition of S. mutans adhesion } & \multicolumn{2}{|c|}{ Binding to $\mathrm{HA}$} \\
\hline & & Casein and saliva together & Casein coated onto sHA & Saliva present & Milk present \\
\hline$\alpha$-Casein & + & + & - & - & + \\
\hline$\beta$-Casein & + & + & - & - & + \\
\hline$\kappa$-Casein & + & + & + & - & + \\
\hline
\end{tabular}

Based on Refs (17) and (18). +: inhibited adhesion; - : inhibition or no effect on binding to hydroxyapatite (HA).

\section{Antibacterial peptides in milk}

Oral epithelial cells and secretory cells in the salivary glands produce antibacterial peptides, refereed to as innate immunity peptides, acting immediately in the mouth upon challenge (24). In general, these peptides are formed by proteolytic cleavage from larger precursor proteins, such as the fungiostatic and bacteriostatic lactoferricin from lactoferrin, and a bacteriostatic and adhesion-preventing RGRPQ-pentapeptide released from salivary acidic proline-rich proteins (25). Recently, caseino-macropeptide (CMP), a C-terminal fragment from bovine $\mathrm{K}$-casein, was shown to inhibit the growth of $S$. mutans and Porfyromonas gingivalis (periodontal disease) (26). Lactoperoxidase and lysozyme are other milk polypeptides that reduce the metabolism of $S$. mutans. Notably, an inhibitory effect of bovine milk on saliva aggregation of $S$. mutans is ascribed to the interference by milk lactoferrin with a streptococcal surface protein antigen (27).

\section{Lactobacilli in fermented milk products do not colonize the mouth}

At present, there are no indications that the bacteria used in yoghurt and fermented products colonize the mouth. Thus, neither Lactobacillus casei nor L. acidophilus was established in the mouth after yoghurt consumption (28). Lactobacilli-containing products are reported to reduce the number of mutans streptococci in saliva (marker for biofilm content), but not endogenous lactobacilli or Candida albicans $(29,30)$.

\section{Milk with saliva-mimicking effects for caries prevention and symptom relief}

In contrast to common belief, dental caries is far from eradicated in children and adolescents living in Sweden: $10-15 \%$ have high disease activity due to genetic or environmental susceptibility or excessive cariogenic challenge. In these groups, which include children with high numbers of mutans streptococci in early childhood, the present preventive measures are insufficient. Using selected milk components (i.e. peptides) to prevent the colonization of mutans streptococci at young ages may enhance caries resistance as the child grows older.

Furthermore, dry mouth conditions, e.g. due to the adverse effects of medication, head and neck irradiation, or primary and secondary Sjögren's syndrome, are associated with oral discomfort and rampant caries, with elevated numbers of mutans streptococci. Milk or milk component-based drinks seem to possess many of the biological and physical properties desired for a saliva substitute. Thus, the need for frequent sipping of liquid to lubricate and moisture the mouth is met at the same time as providing caries protection to highly susceptible individuals. Since hyposalivation is often associated with eating problems and inadequate energy and nutrient intake, a drink based on milk or milk components might be used, serving both purposes.

\section{References}

1. Becker W. Swedes eat healthier - increasing intake of vegetables. Vår Föda 1999; No 1: 24-7. (In Swedish.)

2. Petti S, Simonetti R, Simonetti D'Arca A: The effect of milk and sucrose consumption on caries in 6-to-11-yearold Italian schoolchildren. Eur J Epidemiol 1997; 13:659-64.

3. Petridou E, Athanassouli T, Panagopoulos H, Revinthi $\mathrm{K}$ : Sociodemographic and dietary factors in relation to dental health among Greek adolescents. Community Dent Oral Epidemiol 1996;24:307-11.

4. Papas AS, Joshi A, Belanger AJ, et al. Dietary models for root caries. Am J Clin Nutr 1995;61:417-22S.

5. Shaw JH, Ensfield BJ, Wollman DH: Studies on the relationship of dairy products to dental caries in cariessusceptible rats. J Nutr 1959;67:253-73.

6. Rosen S, Min DB, Harper DS et al: Effect of cheese, with and without sucrose, on dental caries and recovery of Streptococcus mutans in rats. J Dent Res 1984; 63:894-6. 
7. Bowen WH, Pearson SK, VanWuyckhuyse BC, Tabak LA: Influence of milk, lactose-reduced milk, and lactose on caries in desalivated rats. Caries Res 1991:25:283-6.

8. Bowen WH, Pearson SK: Effect of milk on cariogenesis. Caries Res 1993;27:461-6.

9. Krobicka A, Bowen WH, Pearson S, Young DA: The effects of cheese snacks on caries in desalivated rats. J Dent Res 1987;66:1116-9.

10. Jensen ME, Wefel JS: Effects of processed cheese on human plaque $\mathrm{pH}$ and demineralization and remineralization. Am J Dent 1990;3:217-23.

11. Gedalia I, Ionat-Bendat D, Ben-Mosheh S, Shapira L: Tooth enamel softening with a cola type drink and rehardening with hard cheese or stimulated saliva in situ. J Oral Rehabil 1991;18:501-6.

12. Rugg-Gunn AJ, Roberts GJ, Wright WG: Effect of human milk on plaque $\mathrm{pH}$ in situ and enamel dissolution in vitro compared with bovine milk, lactose, and sucrose. Caries Res 1985;19:327-34.

13. Birkhed D, Imfeld T, Edwardsson S: pH changes in human dental plaque from lactose and milk before and after adaptation. Caries Res 1993;27:43-50.

14. Higham SM, Edgar WM: Effects of parafilm and cheese chewing on human dental plaque $\mathrm{pH}$ and metabolism. Caries Res 1989;23:42-8.

15. Grenby TH, Andrews AT, Mistry M, Williams RJ: Dental caries-protective agents in milk and milk products: investigations in vitro. J Dent 2001;29:83-92.

16. Stenudd C, Nordlund A, Ryberg $M$ et al: The association of bacterial adhesion with dental caries. J Dent Res 2001;80:2005-10.

17. Vacca-Smith AM, Van Wuyckhuyse BC, Tabak LA, Bowen WH: The effect of milk and casein proteins on the adherence of Streptococcus mutans to saliva-coated hydroxyapatite. Arch Oral Biol 1994;39:1063-9.

18. Schüpbach P, Neeser JR, Golliard M et al: Incorporation of caseinoglycomacro-peptide and caseinophosphopeptide into the salivary pellicle inhibits adherence of mutans streptococci. J Dent Res 1996;75:1779-88.

19. Reynolds EC: Anticariogenic complexes of amorphous calcium phosphate stabilized by casein phosphopeptides: a review. Spec Care Dentist 1998;18:8-16.

20. Guggenheim B, Schmid R, Aeschlimann JM et al: Powdered milk micellar casein prevents oral colonization by Streptococcus sobrinus and dental caries in rats: a basis for the caries-protective effect of dairy products. Caries Res 1999;33:446-54.

21. Vacca Smith AM, Bowen WH: The effects of milk and kappa-casein on salivary pellicle formed on hydroxyapatite discs in situ. Caries Res 2000;344:88-93.

22. Neeser JR, Golliard M, Woltz A et al: In vitro modulation of oral bacterial adhesion to saliva-coated hydroxy-apatite beads by milk casein derivatives. Oral Microbiol Immunol 1994;9:193-201.

23. Vacca-Smith AM, Bowen WH: The effect of milk and kappa casein on streptococcal glucosyltransferase. Caries Res 1995;29:498-506.

24. Boman HG: Innate immunity and the normal microflora. Immun Rev 2000;173:5-16.

25. Li T, Bratt P, Jonsson AP et al: Possible release of an ArgGlyArgProGln pentapeptide with innate immunity properties from acidic proline-rich proteins by proteolytic activity in commensal streptococcus and actinomyces species. Infect Immun 2000;68:542 5-9.

26. Malkoski M, Dashper SG, O’Brien-Simpson NM et al: Kappacin, a novel antibacterial peptide from bovine milk. Antimicrob Agents Chemother 2001;45:2309-15.

27. Mitoma M, Oho T, Shimazaki Y, Koga T. Inhibitory effect of bovine milk lactoferrin on the interaction between a streptococcal surface protein antigen and human salivary agglutinin, J Biol Chem 2001;276: $18060-5$.

28. Busscher $\mathrm{HJ}$, Mulder $\mathrm{AF}$, van der Mei $\mathrm{HC}$ : In vitro adhesion to enamel and in vivo colonization of tooth surfaces by Lactobacilli from a bio-yoghurt. Caries Res 1999;33:403-4.

29. Petti S, Tarsitani G, D'Arca AS: A randomized clinical trial of the effect of yoghurt on the human salivary microflora. Arch Oral Biol 2001;46:705-12.

30. Nase L, Hatakka K, Savilahti E et al: Effect of longterm consumption of a probiotic bacterium, Lactobacillus rhamnosus GG, in milk on dental caries and caries risk in children. Caries Res 2001;35:412-20.

\footnotetext{
Ingegerd Johansson

Department of Cariology, Umeå University, SE-90। 87 Umeå, Sweden.

E-mail: ingegerd.johansson@odont.umu.se
} 